\title{
Who do ICDS and PDS Exclude and What Can be Done to Change This?
}

\author{
Biraj Swain and M. Kumaran
}

\begin{abstract}
This article looks at the specifics of who the Integrated Child Development Services (ICDS) and the Public Distribution System (PDS) exclude and what can be done to change this. It discusses three different types of exclusion: official exclusion, typically from committing too few resources; implementation flaws; and flawed policy. The article argues that persistence with a poverty cutoff simply perpetuates exclusion. However, the progressive impact of improved judiciability of exclusion due to implementation flaws while making a case for tightening the system cannot be overstated. The article suggests three ways forward: (1) make rights desirable to encourage people to make claims and make ICDS and PDS more universal; (2) ensure that potential innovations such as biometrics, coupons and cash transfers empower the poor, not just the bureaucrats; and (3) empower citizens to fix the ICDS and PDS which will in turn help fix the overall food system.
\end{abstract}

\section{What do ICDS and PDS attempt to do? 1.1 Public Distribution System (PDS)}

The most visible part of the Public Distribution System (PDS) in India is the vast network of 'fair price shops' or 'ration shops' which periodically delivers foodgrains and other essential commodities ${ }^{1}$ at subsidised prices to the member households. There were 5.07 lakh fair price shops as at 31 August 2011 (Department of Food and Public Distribution 2011). On average there is one fair price shop for 2,388 people ${ }^{2}$ 'officially' delivering around 86 tons of foodgrains annually. Another important component of the PDS is the equally vast network of procurement centres managed by the Food Corporation of India (FCI) and other state corporations. Besides distribution through the PDS, the procured foodgrains are also used for maintaining buffer stock, distribution through other welfare schemes and release for open market operations/exports.

The current form of PDS - targeted (TPDS), with subsidised issue prices for the poor emerged from a non-targeted PDS which was in place till 1991, offering 'virtually complete coverage' (Nair 2000) in certain states like Kerala. However, PDS was not always a means for distributing 'subsidised foodgrain'. Prior to the mid-1960s, PDS was more a rationing instrument used in urban areas to control food prices, manage scarcity and address associated political problems (Sobhan 1990).

\subsection{Integrated Child Development Services (ICDS)}

The Integrated Child Development Services (ICDS) is implemented through 12.41 lakh centres (Ministry of Women and Child Development 2012) known as Anganwadi Centres (AWCs), each located in a habitation of $400-800$ people. ${ }^{4}$ The AWC is the focal point for the delivery of services and is run by a team of hired women staff - usually from the local village - known as 'Anganwadi workers' (AWWs) and 'Anganwadi helpers' (AWHs). The centres are best known for providing cooked food and/or foodgrains as supplementary nutrition to the beneficiaries. However, apart from preparing and providing supplementary nutrition, the centres also provide a range of health, nutrition and preschool education services in order to achieve comprehensive infant and child care and development in an integrated manner. ${ }^{5}$ As well as children below the age of six, the programme also aims to address the health and nutrition needs of pregnant and nursing mothers, and of adolescent girls.

Among welfare programmes that address food insecurity through the provision of subsidised/ free foodgrains, wage employment, and cash transfers, ICDS is the sole programme that 
specifically aims to focus on undernutrition and to reach individuals within households.

\section{Who does the programme exclude? \\ 2.1 Officially excluded people}

There are many ways in which the right-holders ${ }^{6}$ under PDS and ICDS are officially excluded. The most obvious amongst them is through not committing adequate resources. Despite high levels of child undernourishment in India and mixed results in addressing the problem (Shiva Kumar 2007), the attempted coverage of ICDS in India still doesn't match the levels recommended by experts. ${ }^{7}$ Similarly, despite studies and reports showing a much larger share of the population facing poverty and food insecurity (Patnaik 2004, 2007), the resource commitment under PDS is limited to a meagre 36 per cent of the Indian population. Another way of officially excluding right-holders involves failing to meet the allocation commitments. Despite being in the final year of the 11th Five Year Plan period we are still 1.5 lakh short of the targeted number of $\mathrm{AWCis}^{8}$ meant to cover at least 1.17 crore potential beneficiaries. ${ }^{9}$

Such massive official exclusion, largely due to low resource commitment, marginalises the majority of India's population who are in distress (Vepa 2010; Walker 2008; Vakulabharanam 2005), especially among the agrarian and rural population. It also disproportionately excludes people from powerless and vulnerable social groups (Social Equity Watch 2010; Mander 2008; Mander and Kumaran 2006; Sinha 2005; Thorat and Lee 2005). The majority of those officially excluded are small farmers (Infochange 2007). In the case of the ICDS programme, those most affected by its limited coverage would be the residents in Dalit, tribal and minority hamlets, usually located on the fringes of the main village.

\subsection{Groups excluded due to implementation flaws}

Apart from overtly subverting funding commitments, another way to exclude rightholders is by not providing an operational structure to deliver the programme and absorb the core resources. Despite planning universal access under ICDS, only 8.37 crore children were officially covered against the target of 15.88 crore children aged 0-6. Similarly, in the case of the PDS, according to official accounts, foodgrains for 25 lakh BPL (below the poverty line) households ${ }^{10}$ were not lifted from the godowns. ${ }^{11,12}$ More worryingly, not all the services that are officially reported as being delivered reach the relevant people. The large-scale survey results from the third National Family Health Survey (NFHS-3) (2005-06) show that on average 'only 32.9 per cent of children (living in an area covered by an AWC) used any AWC services' (Saxena and Srivastava 2009). There are other studies that confirm the low coverage and give much lower access figures (Viswanathan 2006). Similarly, in the case of PDS, the percentage of grain not reaching consumers ranges from 24 to 54 per cent (Khera 2011; Planning Commission 2005). A list of implementation flaws that exclude right-holders as reported in the literature and evaluation studies (Wadwa Committee 2009; Supreme Court Commissioner 2004, 2005, 2007; Planning Commission 2005) is provided below.

1 A poor monitoring system resulting in diversion/leakages that prevent resources from reaching the service delivery points.

2 Local elite control over service delivery which leads to overt corruption by service providers. This happens through employing gatekeepers as service providers or locating resources in the habitation belonging to the powerful local elite.

3 Unaccountable service providers who do not regularly open the service points, or open them at inconvenient times; distribute less than stipulated entitlements in terms of quantity and quality; charge unwarranted prices/or higher than stipulated prices to the beneficiaries; and mislead the beneficiaries with false information.

4 Direct discrimination based on caste, gender and religion.

5 Non-transparency on the part of service providers and monitoring bodies.

6 A minimalist and diluted accountability mechanism further entrenches exclusion and discrimination.

The implementation flaws mentioned above occur in a power structure, where someone benefits by excluding others. The benefits range from shirking work responsibilities to cornering resources meant for the beneficiaries. While the exclusion mechanism at work generally affects the poor and less aware masses, it is especially harsh on landless workers, Dalits, tribals, female children, single women households, religious minorities, disabled and old and destitute people. 
Box 1 Example of three real-life cases of poor (very poor) families who would be left out of the BPL list even if the SECC (Socio Economic Caste Census) is the criterion

1 Jagdish Gujjar (Other Backward Class, OBC) lives with his wife Kamla and his 17-yearold unmarried son who is studying in class 11 . He has two mud huts, and 2.5 bighas $^{13}$ of unirrigated land which is still in his father's name. He is unsure of his age, but guesses it's around 60 years. He is too old to undertake manual labour, though they do allow him to work on NREGA (National Rural Employment Guarantee Act) worksites. Last year he got 21 days of work, for which he was paid Rs 700, or about Rs 35/day.

2 Uddi Gujjar is a widow who has two sons - Hanuman (16-17 years old) who studied till class 6, and Prithviraj (15 years old) currently in class 11. She has one bigha of unirrigated land in her name and one bigha is in the names of her two sons. Her husband died of TB ten years ago, when her sons were still very young. She continues to live in his village but not with his family. Whether her house will be categorised as $k a c h h a^{14}$ or pukk $a^{15}$ depends on the discretion of the investigator. According to her, it is $k a c h h a$ but because the roof is made of chaadar $^{16}$ and cement it may be considered pukka.

3 Om Prakash Berwa (SC) lives with his wife Jena Devi and younger son Soji, aged 18 years, who is studying. He owns three bighas of unirrigated land. The family survives mainly on casual labour, such as construction labour and NREGA work. They live in a small brick house with a single room.

Source Drèze (2011).

\subsection{Groups excluded due to discriminatory and flawed} policy

A flawed policy is another major source of exclusion under these two schemes. Some State Governments have recognised these policy flaws and have addressed them to make the schemes more inclusive. However, despite the good example set by these states, the Central Government continues to ignore the lessons and continues to follow flawed exclusionary policies.

\subsection{Targeting to exclude the poor}

The major policy flaw that is widely debated and contested by civil society is the attempt to target and identify poor households under PDS. The imposition of artificially low poverty figures by the Central Government on states and the attempt to 'objectively' identify the poor has in fact resulted in mass exclusion of the poor, as documented by numerous studies and the government's own reports (Mane 2006; GoI 2002; Planning Commission 2005, 2007). There are many states which have shown that universal PDS is a much better way of reaching the poor and addressing the food security concerns of the masses (Khera 2011).

\subsection{Policing the poor}

While the government is complicit with power groups who manage to subvert the schemes at macro and micro levels, it focuses its attention on policing and preventing frauds and misuse of ration cards by poor households. This focus has in turn delayed the formulation of policies that ensure inclusion of most vulnerable groups such as migrant labourers, homeless people, urban poor in unrecognised urban slums, communities residing in forest villages and displaced communities (Supreme Court Commissioners 2005, 2007 and 2008).

\subsection{Perpetuating social discrimination}

Numerous reports show that the socioeconomic status of Dalit/tribal people and minorities is worse than that of dominant caste groups (Sachar Committee 2006; Gragnolati et al. 2005; Ministry of Health and Family Welfare 2002). In addition, studies also show that access to services for these social groups is much worse than for other social groups (Acharya 2010; Mander and Kumaran 2006; Sinha 2005; Thorat and Lee 2005). A major policy flaw in these two schemes is that instead of addressing social discrimination associated with gender, caste and disability, they perpetuate these. On the pretext of efficiently locating these service infrastructures in a central location, the entire scheme is placed in 'upper' caste habitations (Social Equity Watch 2010), legitimising the core-periphery relation between the dominant 
'upper' caste habitations and the marginalised habitations of Dalit, tribal and religious minorities. This, along with the appointment of 'gatekeepers' from the dominant caste groups as service providers makes it very difficult for the people from marginalised communities to demand accountability (Social Equity Watch 2010). Similarly, the ownership of household ration cards rests with men and increases women's dependence on men within the household. The fair price shop dealerships rest entirely with men, increasing women's dependence on men beyond the household. Similarly, under the ICDS, take-home rations are provided and it is assumed that the goal of supplementary nutrition for women is achieved. In case of transgender persons, the nonissuance of ration cards further legitimises their invisibilisation.

\subsection{Minimalistic costing}

The utilitarian economic ideology which prescribes 'user charges' for minimalising economic costs, is applied differently to these two schemes. The schemes are strategically underfunded in a way that at each level attempts are made to pass the cost on to the 'real' users. Therefore the burden of implementation is passed by Central Government to the State Governments, which then attempt to pass this on to the panchayats and service providers. Hence the underpaid and overburdened AWWs and the fair price shop dealers who are expected to run unviable shops, gain moral legitimacy to charge the beneficiaries illegally, either through overcharging them or under-serving them. While the users are not officially expected to pay for the services, they end up paying for them in the form of forgone services due to corrupt practices.

For example, unwarranted cost rationalisation results in: overburdened AWWs who are unable to perform essential ICDS functions (Saxena and Srivastava 2009; CIRCUS 2006); unviable fair price shops which cannot survive without corruption (Standing Committee on Food, Consumer Affairs and Public Distribution 2005); AWWs serving low-quality food which is neither nutritious nor palatable to children (CIRCUS 2006); beneficiaries unable to purchase rations due to high prices at fair price shops (Supreme Court Commissioners 2005); and private partners severely lowering the quality of services (Diwakar 2010). Poor people with low purchasing power are invariably the most affected group due to such underfunding of services. Further, the poor living in resource-poor districts and states are the worst affected (Supreme Court Commissioners 2005).

In some places, the local authorities even started charging the users officially with a stated objective of filling up the crucial funding gap (Supreme Court Commissioners 2004, 2005). However, the Supreme Court had banned overcharging or reducing entitlements under these two schemes.

\subsection{Missing elements in the nutrition and health agenda}

Flawed policies lead directly to the exclusion of some groups or areas. In the ICDS, the lack of emphasis on health and nutritional services for children aged $0-3$ and their mothers, is a major drawback which excludes a highly vulnerable group. Similarly, the potential to diversify PDS beyond rice and wheat is completely unexplored.

\subsection{Favouring large players and corporate interest}

While setting up massive schemes such as the PDS and ICDS it is important to ensure that the resources invested are channelled towards ensuring the welfare of the intended beneficiaries rather than serving the vested interests of a few or benefiting big players. In the case of ICDS, despite the huge opportunity to procure and process food in locally beneficial ways through women's groups and from small farmers, there is an unjustified tendency to open up this avenue to private companies selling ready-made processed food (Baru et al. 2008). Similarly, the PDS provides a big opportunity to procure from small and marginal farmers, rather than procuring from large farmers in a few states (GoI 2002). The tendency to exclude the small and marginal farmers and women's groups is a result of policy shortsightedness, which refuses to see the poor as producers who could be food-secure in a different way.

\section{What can be done to change this?}

Suggesting an agenda for change is a more difficult task than diagnosing forms of exclusion as it involves strategising in the context of the prevailing political economy. Therefore no quickfix take-aways are attempted here. Rather, after a brief analysis of the current policy climate, a broader agenda for change is suggested.

The current policy climate assessed in the light of the proposed National Food Security Bill, 
presents quite bleak prospects for addressing exclusion in the PDS and ICDS.

1 Firstly, the proposed Bill continues with the philosophy of targeting by identifying the poor when implementing the PDS, and is therefore likely to perpetuate the official exclusion described earlier. However, the proposed upward changes in targeting caps and reiteration of the aim to cover every child with the supplementary nutrition programme (SNP) under ICDS, are positive signs and point to possibilities for further changes in the government's rigid stance.

2 Secondly, with regard to exclusion due to implementation flaws, the scope for justiciability, as proposed in the Bill is a welcome step towards fixing accountability for implementation flaws. However, the current grievance redress mechanism proposed under the law is vaguely defined and can be subverted.

3 Thirdly, in the context of exclusion due to faulty policies, there is a major disappointment. The proposed Bill still exhibits faith in arriving at a mechanism to identify the poor. Similarly, it proposes to take forward the legacy of discriminatory policies and cost 'rationalisation', by not suggesting any fundamental shifts. The worst part of the Bill is that it completely neglects the nutrition agenda by ignoring non-SNP services under ICDS and opens up the scope for a corporate takeover through introducing ready-to-use food. Despite these limitations, some of the proposed shifts are welcome. These include the promise of providing ration cards in the woman's name and the proposal to cover migrant labourers under the Act.

\subsection{Agenda for action}

The proposed Bill offers huge opportunities for bringing about a fundamental shift in the way PDS and ICDS work. That shift is more likely if the government recognises that community ownership and demand hold the key to success in addressing exclusion in such massive schemes. Such community ownership would be achieved only when rights conferred through the Bill, including grievance-redressal, are exercised by the people. However, mere creation of rights does not mean they would automatically get exercised. Prolonged efforts and struggle are needed to achieve the required transition.
This requires a fundamental shift in the policy assumptions of the government. The government has to recognise that it is far easier for people to exercise their rights when the bundles of rights are more desirable. For instance, at places where the PDS is well resourced, providing adequate, affordable, good-quality and diversified commodities, communities are more vocal when their rights get violated. Such an understanding would counter and replace the current official diagnosis which laments lack of awareness and interest on the part of communities and cites that as the reason for dysfunctional and defunct community-level monitoring groups.

Similarly, it is important to have rights which unify the masses with common interests and provide stronger solidarity options rather than dividing them on the basis of false BPL lines. It is also argued in many studies that when the service delivery points also cater to the relatively better-off sections of society, the involvement of socially and politically better-placed sections makes the service providers more accountable and improves the quality of services. The experiences in Kerala and Tamil Nadu are good examples to support this. Also, widening the constituency of right-holders through procurement from small and marginal farmers and women's groups would be an important step towards encouraging democratic processes.

Therefore, creating a good-quality universal PDS and ICDS would be an essential step in translating these services into rights, which people would aspire to rally around. Once community groups start exercising their rights, most of the problems plaguing the current PDS and ICDS could be effectively solved.

Secondly, it is important to recognise that if instead of investing in building a better PDS and ICDS, the resources are diverted towards quick fixes, such as IT solutions, food coupons and cash transfers, then the task at hand would become more difficult. The current plans to use IT solutions such as a UID (Unique Identification Number) and biometric identification, are more likely to confer power on administrators and groups who would supposedly police and monitor the poor. If these quick fixes have to be used at all, then they should be directed towards empowering the people. It is the service providers and government officials - the key 
sources of massive leakages - who need to be monitored by people through UIDs and smartcards.

Thirdly, in the new universal systems, one has to discard the misplaced policy assumption that attempts to address discrimination would put at risk the larger goal of achieving food security. ${ }^{17} \mathrm{It}$ is important to recognise that when social discrimination is a major reason for food insecurity it would be impossible to address it without challenging discrimination. Therefore mechanisms to mobilise, organise and empower the social groups facing discrimination are an important parallel step that needs to be taken to achieve inclusiveness in the scheme.

\section{Notes}

1 For example, pulses and kerosene.

2 Estimate based on the provisional population total of Census 2011.

3 Estimate based on 2010/11 foodgrain offtake figures as given by the Department of Food and Public Distribution (2011).

4 A 300-800 population norm is used in tribal/ riverine/desert/hilly and other difficult areas and a 150-400 population norm for Mini ICDS centres.

5 Apart from supplementary feeding, ICDS includes a package of five essential services:

(1) non-formal preschool education;

(2) nutrition and health education;

(3) immunisation; (4) health check-ups; and

(5) referral services (in conjunction with village-level health workers).

6 As defined by the Supreme Court of India in the right to food case - Civil Writ (196 of 2001) PUCL vs UoI and others.

7 In 2006 the Supreme Court (Civil Writ 196 of 2001 PUCL vs UoI and others) looking at the gravity of child malnutrition in India has decreed that ICDS must be universal. The XI Plan in turn budgeted for 14 lakh AWGs, far fewer than the requirement for 17 lakh AWCs estimated by Drèze and Shonali Sen (2004) for the National Advisory Committee.

8 Calculation based on Number of Operational AWCs reported by the Ministry of Women and Child Development (2011).
Finally, it is true that putting in place goodquality, universal and inclusive services under ICDS and PDS is only a small step towards achieving food and nutritional security for excluded groups. However, in the light of fierce opposition from policymakers and a few experts, this small step assumes much greater significance. It is important to remember that only after the $1990 \mathrm{~s}$, in the context of dogmatic pursuit of free-market policies, were these two schemes seriously considered as a means to protect food entitlements of the poor and vulnerable. ${ }^{18}$ Now it is important to also consider these schemes as a means of mobilising the community towards fixing the broken food system in India.

9 Calculation based on average beneficiary per AWC (Ministry of Women and Child Development 2011).

10 Based on BPL offtake figures reported for 2009/10 (Department of Food and Public Distribution 2011).

11 Godowns are storehouses where PDS foodgrain is stored.

12 However, it must be noted, in this regard, that the situation has improved over the last decade. Earlier in 2001, in the case of PDS, around 4.2 crore BPL households did not claim the allocated foodgrains. Similarly in ICDS, during 2003-04, there were only 3.42 crore children aged $0-6$ officially covered.

13 Bigha - a traditional unit of land area in South Asia. It varies in size from region to region but is generally less than one acre (0.4ha).

14 Kachha - a structure that is partly made of mud, thatch or wood.

15 Pukka - a house that is built entirely of concrete cement and has four walls and a roof.

16 Chaadar - asbestos sheets.

17 For example, on these grounds, officials do not allow siting of the ICDS in Dalit hamlets. Instead they place it in general caste hamlets, where the Dalits find it difficult to access the scheme.

18 See Sobhan (1990) and Srivastava (2006). 


\section{References}

Acharya, Sanghamitra (2010) Access to Health Care and Pattern of Discrimination - A Study of Dalit Children in Selected Villages of Gujarat and Rajasthan, Working Paper 01.02, New Delhi: Indian Institute of Dalit Studies and UNICEF

Baru, Rama, V.; Dasgupta, Rajib; Deshpande, Mita and Mohanty, Aparna (2008) 'Full Meal or Package Deal?', Economic and Political Weekly 43.24: 20-2

GIRGUS (Gitizens Initiative for Rights of Children Under Six) (2006) Focus on Children Under Six, www.righttofoodindia.org/data/rtf06focusreport abridged.pdf (accessed 2 April 2012)

Department of Food and Public Distribution (2011) Monthly Foodgrain Bulletin, November, New Delhi: Government of India

Diwakar, G. Dilip (2010) Child Care Remains Uncared for: Situational Assessment of the Integrated Child Development Service (ICDS) Centres in the Relocation Settlements of Chennai District, New Delhi: Booksforchange

Drèze, Jean (2011) 'Kaun Banega Scorepati?', The Hindu, 28 November 2011

Drèze, Jean and Shonali Sen (2004) 'Universalisation with Quality: An Agenda for ICDS', mimeo, National Advisory Committee, New Delhi

GoI (Government of India) (2002) Report of the High Level Committee on Long-term Grain Policy, New Delhi: Government of India, Department of Food and Public Distribution, Ministry of Food and Consumer Affairs

Gragnolati, Michele; Shekar, Meera; Das Gupta, Monica; Bredenkamp, Caryn and Lee, YiKyoung (2005) India's Undernourished Children: A Call for Reform and Action, HNP Discussion Paper, World Bank, http://siteresources.worldbank.org/ SOUTHASIAEXT/Resources/2235461147272668285/IndiaUndernourishedChildre nFinal.pdf (accessed 12 May 2010)

Infochange (2007) 50\% of Small Farm Households have no Ration Cards: NSSO Survey, InfoChange News and Features, www.infochangeindia.org/ bookandreportsst 123.jsp (accessed 24 April 2012)

Khera, Reetika (2011) 'Revival of the Public Distribution System: Evidence and Explanations', Economic and Political Weekly 46.44/45

Mander, Harsh (2008) 'Living with Hunger: Deprivation Among the Aged, Single Women and People with Disability', Economic and Political Weekly 43.17: 87-98
Mander, Harsh and Kumaran, M. (2006) 'Social Exclusion in ICDS: A Sociological Whodunit?', mimeo, Centre For Equity Studies, www.righttofoodindia.org/data/manderkumara n06icdsexclusion.doc (accessed 2 April 2012)

Mane, Rahul Prahlad (2006) 'Targeting the Poor or Poor Targeting: A Case for Strengthening the Public Distribution System of India', Journal of Asian and African Studies 41.4: 299-317

Ministry of Health and Family Welfare (2002) National Health Policy, Government of India, Ministry of Health and Family Welfare, www.mohfw.nic.in/NRHM/Documents/ National_Health_policy_2002.pdf (accessed 2 April 2012)

Ministry of Women and Child Development (2012) Status Report 31.10.2011, Government of India, www.wcd.nic.in/icdsdocument/ statewise5year.pdf (accessed 15 March 2012)

Ministry of Women and Child Development (2011) ICDS Monthly Progress Report Update as on 02.02.2011, Government of India, http://wcd.nic.in/QPR1210.pdf (accessed 24 April 2012)

Nair, K.N. (2000) 'Food Security and the Public Distribution System in Kerala', in K. Krishaji and T.N. Krishnan (eds), Public Support for Food Security - The Public Distribution System in India, New Delhi: Sage Publications: 314-30

Patnaik, Utsa (2007) 'Neoliberalism and Rural Poverty in India', Economic and Political Weekly 42.30: 3132-50

Patnaik, Utsa (2004) 'The Republic of Hunger', Social Scientist, Sept-Oct: 9-35

Planning Commission (2007) Eleventh Five Year Plan 2007-2012 - Vol II, New Delhi:

Government of India

Planning Commission (2005) Performance Evaluation of Targeted Public Distribution System (TPDS), New Delhi: Government of India, Programme Evaluation Organisation

Sachar Committee (2006) Social, Economic and Educational Status of the Muslim Community in India, Prime Minister's High Level Committee, Government of India, www.mfsd.org/sachar/ leafletEnglish.pdf (accessed 24 April 2012)

Saxena, N.C. and Srivastava, Nisha (2009) 'ICDS in India: Policy, Design and Delivery Issues', IDS Bulletin 40.4: 45-52

Shiva Kumar, A.K. (2007) 'Why are Levels of Child Malnutrition Not Improving?', Economic and Political Weekly 42.15: 1337-45

Sinha, Sachidanand (2005) 'Reaching out to Undernourished Children: Social Inequalities 
and Policy Perspectives', Journal of Health And Development 4: 71-90

Sobhan, Rehman (1990) 'The Politics of Hunger and Entitlement', in Jean Drèze and Amartya Sen (eds), The Political Economy of Hunger: Volume 1: Entitlement and Well-being, Oxford: Clarendon Press: 79-113

Social Equity Watch (2010) Briefing PaperNational Infrastructure Equity Audit, New Delhi: Praxis - Institute of Participatory Practices, www.praxisindia.org/files/NIEA-Final.pdf (accessed 2 April 2012)

Srivastava, Pradeep (2005) 'Poverty Targeting in India', in John Weiss (ed.), Poverty Targeting in Asia, UK: Asian Development Bank and Institute and Edward Elgar Publishing: 34-78

Srivastava, Ravi (2006) 'Expanding Social Security in a Neo-Liberal World: India's Tryst with Rights-Based Approaches', Hopper Lectures, University of Guelph, Guelph, 10 May 2010, www.uoguelph.ca/research/ international/index.shtml

Standing Committee on Food, Consumer Affairs and Public Distribution (2005) Fourteenth Lok Sabha, New Delhi: Government of India, Ministry of Consumer Affairs, Food and Public Distribution (Department of Food and Public Distribution)

Supreme Court Commissioners (2008) Eighth Report of Supreme Court Commissioners (PUCL vs UOI and others, Civil Writ 196 of 2001), 2008, www.sccommissioners.org/Reports/Reports/ (accessed 2 April 2012)

Supreme Court Commissioners (2007) Seventh Report of Supreme Court Commissioners (PUCL vs UOI and others, Civil Writ 196 of 2001), 2007, www.sccommissioners.org/Reports/Reports/ (accessed 2 April 2012)
Supreme Court Commissioners (2005) Sixth Report of Supreme Court Commissioners (PUCL vs UOI and others, Civil Writ 196 of 2001), December, 2005, www.sccommissioners.org/Reports/Reports/ (accessed 2 April 2012)

Supreme Court Commissioners (2004) Fifth Report of Supreme Court Commissioners (PUCL vs UOI and others, Civil Writ 196 of 2001), 2004, www.sccommissioners.org/Reports/Reports/ (accessed 2 April 2012)

Thorat, Sukhadeo and Lee, Joel (2005) 'Caste Discrimination and Food Security Programmes', Economic and Political Weekly 40.39

Vakulabharanam, V. (2005) 'Growth and Distress in a South Indian Peasant Economy During the Era of Economic Liberalisation', Journal of Development Studies 41.6: 971-97

Vepa, S. Swarna (2010) Bearing the Brunt - Impact of Rural Distress on Women, New Delhi: Sage

Viswanathan, Brinda (2006) 'Access to Nutritious Meal Programmes: Evidence from 1999-2000 NSS Data', Economic and Political Weekly 41.6: 497-505

Wadwa Committee (2009) Status report on PDS, Wadwa Committee Appointed by Supreme Court of India in PUCL vs UOI and Others Civil Writ 196 of 2001, www.righttofoodindia.org/pds/pds justice_wadhwa_committee_report.html (accessed 2 April 2012)

Walker, Kathy Le Mons (2008) 'Neoliberalism on the Ground in Rural India: Predatory Growth, Agrarian Crisis, Internal Colonization, and the Intensification of Class Struggle', Journal of Peasant Studies 35.4: 557-620 